Gut, 1987, 28, S1, 189-192

\title{
Simultaneous measurement of intestinal crypt cell production rate and water absorption
}

\author{
R A GOODLAD, J A PLUMB, AND N A WRIGHT \\ From the Department of Histopathology, Royal Postgraduate Medical School, Hammersmith Hospital, \\ London
}

SUMMARY Intestinal cell proliferation and cell production is best quantified by measuring the rate of accumulation of vincristine arrested metaphases in microdissected intestinal crypts to determine the crypt cell production rate (CCPR). Studies of intestinal adaptation could be much more informative if a valid measure of intestinal function could also be included. One such method is the water absorption capacity. The CCPR of the jejunum and intestinal water absorption were measured in 19 groups of hypo and hyperproliferative rats which were in a 'steady state' of cell production and turnover. The minimum values were obtained after hypophysectomy and the maximum values were observed in lactation. Crypt cell production rate and absorption were significantly correlated $(p<0.001)$ to each other. There was a significant $(p<0.001)$ correlation between both CCPR and absorption and dry weight of the intestinal segment studies and food intake. Body weight was a poor predictor of either CCPR or absorption. The combined study of CCPR and water absorption is thus a practical and convenient approach to the study of intestinal cell proliferation and intestinal adaptation.

The relationship between cell production and intestinal function is of great interest in studies of intestinal adaptation. Intestinal cell production can be measured in several ways, some of which have been extensively criticised. ${ }^{121}$ One method which is robust enough to withstand criticism and account for the many changes which can occur in an adapting intestine is the crypt cell production rate (CCPR) method. ${ }^{1}$

Warm ischaemia and the presence of unstirred layers can confound absorption measures; however, these can be avoided if a single pass segmented flow technique is used. ${ }^{34} \mathrm{~A}$ preliminary investigation showed that vincristine had no significant effect on intestinal water absorption within the time course of a crypt cell production rate assay. The two techniques were thus applied to the following group of rats: starved ${ }^{56}$ hypophysectomy, ${ }^{7}$ intestinal bypass in selfemptying blind loops, ${ }^{8}$ hypothermic hyperphagia, ${ }^{9}$ lactation ${ }^{1011}$ and experimentally induced diabetes. ${ }^{12}$ Several groups with normal proliferative rates (the control groups for the various treatments) were also included.

Address for correspondence: Dr R A Goodlad, Dept of Histopathology, Royal Postgraduate Medical School, Hammersmith Hospital, Ducane Road, London.

\section{Methods}

ANIMALS

Male Wistar rats were used (Olac Ltd, Blackthorn, Oxon, UK). They were kept in wire bottomed cages and fed a standard laboratory diet (Labshure PRD, Christopher Hill, Poole, Dorset). Nineteen groups of rats containing eight animals were chosen to represent the range of proliferative rates found in models of intestinal adaptation. The hypoproliferative models were starvation, hypophysectomy, and intestinal bypass. Hyperproliferative models included hypothermic induced hyperphagia, streptozotocin induced diabetes and lactation. The various control groups for these models were also included. Preliminary results showed that there were no significant sex differences in CCPR and absorptive rate thus female rats were included (pregnant and lactating).

\section{CRYPT CELL PRODUCTION RATE}

Rats were injected with $1 \mathrm{mg} / \mathrm{kg}$ vincristine sulphate at $900 \mathrm{am}$, killed at timed intervals. One centimetre lengths of intestine were fixed in Carnoys fluid and the tissue samples were stored in $70 \% \mathrm{v} / \mathrm{v}$ ethanol. They were later hydrolysed in $1 \mathrm{M} \mathrm{HCl}$ for six minutes and stained with Schiff's reagent. The intestinal crypts 
were microdissected; the number of arrested metaphases in 10 crypts was counted and the mean values plotted against time after injection. The slope of the line, fitted by least squares linear regression, gave the crypt cell production rate (CCPR). ${ }^{1}$

INTESTINAL PERFUSION

The 'segmented-flow' technique for single pass luminal perfusion of Fisher and Gardener ${ }^{4}$ was used. The perfusion apparatus consisted of two water jacketed gut baths mounted on a frame. Each gut bath had a flexible water jacketed tube to supply the perfusate and warm moist gas. A peristaltic pump generated the segmented flow by pumping gas and fluid into a glass $Y$ connector. Rats were anaesthetised with ether, the abdomen opened. A glass catheter was tied into the jejunum and the intestine was perfused with gassed $0.12 \mathrm{M} \mathrm{NaCl} / \mathrm{NaHCO} 3$ 'saline' solution at $38^{\circ} \mathrm{C}$. When the solution started to inflate the caecum, a cannula was tied into the distal ileum. The gut was then rinsed through with alternate pulses of perfusion medium and warm saline moistened $\mathrm{CO} 2 /$ $02(95: 5)$. The mesenteric arteries were then clamped and the mesentery was gently stripped away. The gut was then suspended in a gassed gut bath. The perfusion medium was a modified Krebs-Henseleit bicarbonate solution ( $\mathrm{pH} 7.4)$ equilibrated with the gas mix. ${ }^{4}$ It contained $28 \mathrm{mmol} / 1$ glucose and $141 \mathrm{nmol} / \mathrm{ml}$ phenol red. The water absorption rates were determined directly from the weight of fluid secreted during the three consecutive five minute periods after the first and second five minute collections.

\section{Results}

The rats in the five control groups had a mean weight of $288.6 \pm 29.8 \mathrm{~g}$, ate $25.9 \pm 2.2 \mathrm{~g}$ and the length of the segments of intestine perfused (from ligament of Trietz to $5 \mathrm{~cm}$ above the ileocaecal valve) was $78 \cdot 3 \pm 9 \cdot 3 \mathrm{~cm}$ and the dry weight of this segment was $1 \cdot 41 \pm 0 \cdot 18 \mathrm{~g}$. The absorption rate was $134 \cdot 4 \pm 10 \cdot 3 \mu \mathrm{l} /$ $\mathrm{cm} / \mathrm{h}(10828 \pm 2120 \mu \mathrm{l} / \mathrm{gut} / \mathrm{h})$ and the CCPR was $25 \cdot 0 \pm 1 \cdot 5$ cells $/$ crypt $/ \mathrm{h}$.

The correlations between the various groups are shown in the Table. While most factors were significantly correlated (by both the Pearson product moment method and by Spearmans Rank correlation) body weight and length of small intestine were poor predictors of CCPR (and absorption). Absorption and CCPR were significantly correlated (Figure) and it made little difference whether absorption per $\mathrm{cm}$ or per gut was considered. The highest correlation coefficients were seen between food intake gut dry weight, absorption and CCPR (Figure).

\section{Discussion}

Vincristine did not affect our measure of absorption over the time scale of the CCPR method (CCPR studies in the gut should be completed within three hours or the arrested metaphases may start to decay. ${ }^{1}$

The mean values for the control groups in this study were very similar to previously published values using similar techniques ${ }^{5-13}$ which confirms that the combination of these techniques did not alter the measured values. The combination of the two techniques should prove to be very useful as the determination of intestinal cell proliferation by the quantification of vincristine arrested metaphases in microdissected crypts has several advantages over other proliferative measures. It is a rate measure and can detect changes in cell production irrespective of whether they are the result of alterations in the cell cycle time, crypt size or growth fraction and the technique also avoids the problems associated with the quantification of cell types in sectioned material and with the use of tritiated thymidine. ${ }^{1}$ Intestinal water absorption measurement also has several advantages over other absorption methods; it gives a holistic measure of gut function and is not distorted by the presence of unstirred layers of fluid next to the absorptive cells or by the rapid loss of absorptive

Table Correlation between various groups

\begin{tabular}{|c|c|c|c|c|c|c|}
\hline & $\begin{array}{l}\text { Rat } \\
\text { weight }\end{array}$ & $\begin{array}{l}\text { Small } \\
\text { intestine } \\
\text { (length) }\end{array}$ & $\begin{array}{l}\text { Gut } \\
\text { weight }\end{array}$ & $\begin{array}{l}\text { Absorption } \\
\text { per cm }\end{array}$ & $\begin{array}{l}\text { Absorption } \\
\text { per gut }\end{array}$ & $C C P R$ \\
\hline Length SI & 0.40 & & & & & \\
\hline Dry weight gut & $0.69+$ & $0.82 \ddagger$ & & & & \\
\hline Absorption per $\mathrm{cm}$ & $0.57^{*}$ & $0 \cdot 72 \ddagger$ & $0.83 \ddagger$ & & & \\
\hline Total absorption & $0.51^{*}$ & $0.88 \ddagger$ & $0.87 \ddagger$ & $0.96 \ddagger$ & & \\
\hline CCPR & 0.42 & $0.55^{*}$ & $0.71 \ddagger$ & $0.78 \ddagger$ & $0.74 \ddagger$ & \\
\hline Food intake & $0.68+$ & $0.58 \dagger$ & $0.78 \ddagger$ & $0.82 \ddagger$ & $0.78 \ddagger$ & $0 \cdot 78 \ddagger$ \\
\hline
\end{tabular}

* = Significantly correlated (Pearsons method) $\mathrm{p}<0.05 ; \dagger=$ Significantly correlated (Pearsons method) $\mathrm{p}<0.01$; $\ddagger=$ Significantly correlated (Pearsons method) $p<0.001$ 

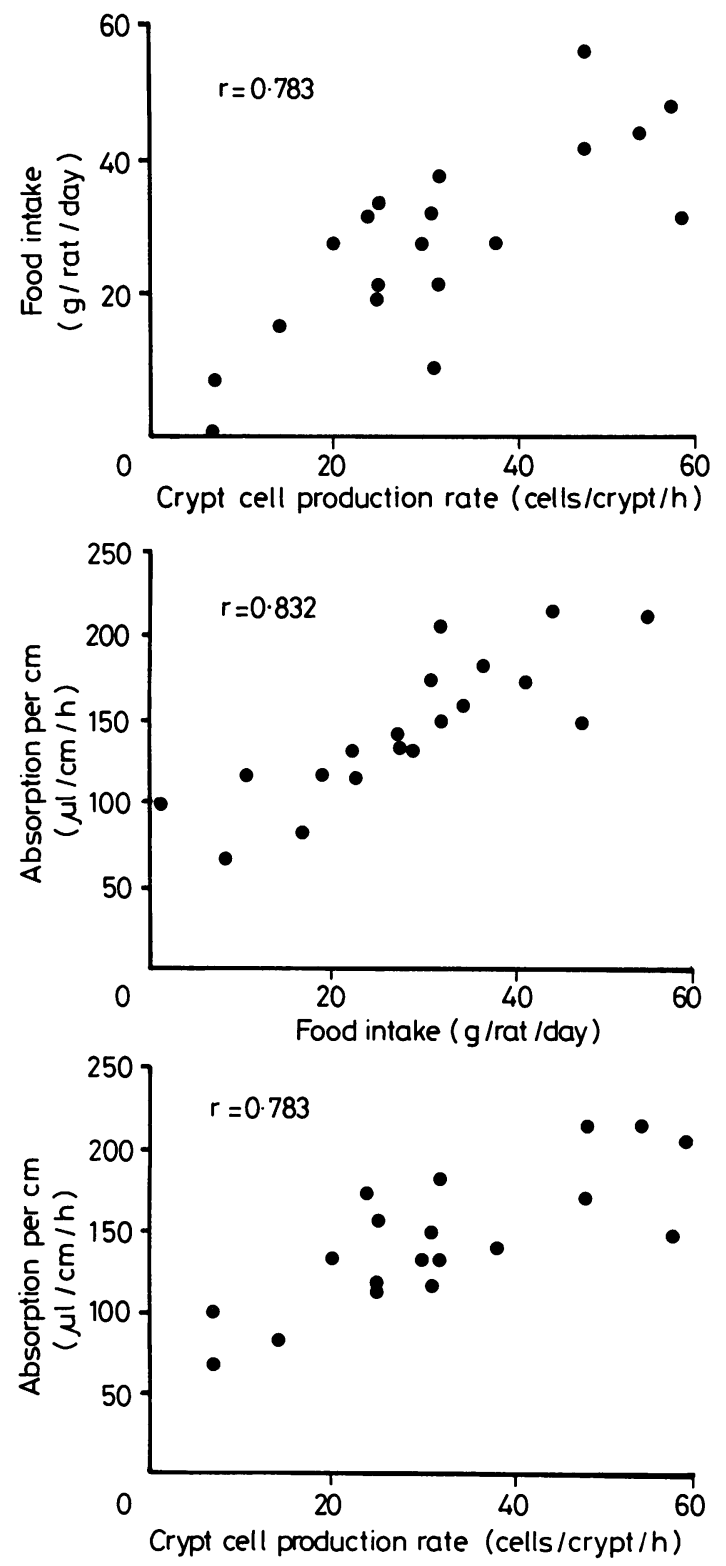

Plots of absorption versus crypt cell production rate $(C C P R)$ and $C C P R$ and absorption versus food intake.

function associated with warm ischaemia. When the dynamic renewal system of the mouse gut is in a state of equilibrium there is an almost direct equivalence between crypt cell number and villus cell number ${ }^{14}$ and the results of the present study suggests that the same applies to the rat gut. This may not be the case when the system is perturbed. ${ }^{15}$ Wright et $a l^{145}$ determined cell population directly in micro- dissected mouse crypts and villi, which is the method of choice for the determination of crypt or villus cell populations ${ }^{1}$ as simple estimates of crypt or villus height can be very misleading. ${ }^{1617}$ Rat villi are considerably larger than mouse villi and their convoluted shape makes their microdissection almost impossible. There is thus a great need for another method for assessing villus cell population and the results of the present study suggest that the measure of the in vitro water absorptive capacity may be of use.

This study also suggests that in the adapted small bowel the rate of cell proliferation in the jejunum generally reflects the state of the rest of the small intestine, thus the quantification of CCPR in one site may be valid in these models.

When the bowel is in a relatively 'steady state' of cell production the migration water absorption gives a more precise measure than the CCPR because it is a holistic method. It is also less labour intensive; and with a two bath system eight to 10 animals can be measured in a morning. The CCPR method must still remain as the method of choice for measuring intestinal proliferative status.

The food intake immediately before the measurement of proliferation and absorption was highly correlated with these measures. Although systemic and other factors have an important role to play in the control of intestinal epithelial cell proliferation they are also very dependent on food intake. Humoral factors are clearly involved in the massive proliferative response of the gut in lactation ${ }^{18}$ but this response can be abolished if hyperphagia is prevented. ${ }^{19}$ The effects of food intake on intestinal epithelial cell is perhaps best shown by the profound intestinal atrophy seen in intravenously fed animals. ${ }^{2021}$ The mechanisms involved in the trophic response to 'luminal nutrition' may involve the direct action of nutrients on enterocytes, their stimulation of the requirements of 'intestinal workload', ${ }^{22}$ the actions of endogenous secretions and the effects of hormones. ${ }^{23} 24$

We thank the Cancer Research Campaign for financial assistance. We also thank Dr C J Winder for providing the lactating rats.

\section{References}

1 Goodlad RA, Wright NA. Quantitative studies on epithelial replacement in the gut. In: Titchen T A., ed. Techniques in the life sciences. Techniques in digestive physiology. Vol P2. Ireland: Elsevier Biomedical Press, 1982: 212/1-23.

2 Wright NA, Alison M. The biology of epithelial cell populations. Vol 1 Oxford: Clarendon Press, 1984;

3 Lerner JA, Miller DS. Techniques in intestinal absorption studies. In: Titchen T A, ed. Techniques in the life 
sciences. Techniques in digestive physiology. Vol P2. Ireland: Elsevier Biomedical Press, 1982: 207/1-25.

4 Fisher RB, Gardner MLG. A kinetic approach to the study of absorption of solutes by isolated perfused small intestine. J Physiol (Lond) 1974; 241 : 211-34.

5 Goodlad RA, Al-Mukhtar MYT, Ghatei MA, Bloom SR, Wright NA. Cell proliferation, plasma enteroglucagon and plasma gastrin levels in starved and refed rats. Virch Arch [Cell Pathol] 1983; 43: 55-62.

6 Goodlad RA, Wright NA. The effects of starvation and refeeding on intestinal cell proliferation in the mouse. Virch Arch [Cell Pathol] 1984; 45: 63-73.

7 Taylor B, Murphy GM, Dowling RH. Pituitary hormones and the small bowel: effect of hypophysectomy on intestinal adaptation to small bowel resection in the rat. Eur J Clin Invest 1979; 9: 115-27.

8 Robinson JWL, Menge H, Schraeder P, Riecken EO, Van Melle G. Structural and functional correlations in the atrophic mucosa of self-emptying blind loops of rat jejunum. Eur J Clin Invest 1980; 10: 393-401.

9 Rothwell NJ, Stock MJ. Similarities between cold- and diet-induced thermogenesis in the rat. Can J Physiol Pharmacol 1980; 58: 842-8.

10 Fell BF, Smith KA, Campbell RM. Hypertrophic and hyperplastic changes in the alimentary canal of the lactating rat. $J$ Pathol Bacteriol 1960; 85: 179-88.

11 Harding JD, Cairnie AB. Changes in intestinal cell kinetics in the small intestine of lactating mice. Cell Tissue Kinet 1975; 8: 135-44.

12 Nakabou Y, Okita C, Takano Y, Hagihira H. Hyperplastic and hypertrophic changes of the small intestine. J Nutr Sci Vitaminol 1974; 20: 227-34.

13 Gardner MLG, Plumb JA. The absorptive viability of isolated intestine prepared from dead animals. $Q J \operatorname{Exp}$ Physiol 1978; 68: 93-5.

14 Wright NA, Irwin M. The kinetics of villus cell populations in the mouse small intestine. I. Normal villi: the steady state requirement. Cell Tissue Kinet 1982; 15: 595-609.
15 Wright NA, Al-Nafussi A. The kinetics of villus cell populations in the mouse small intestine. II. Studies on growth control after death of proliferative cells induced by cytosine arabinoside, with special reference to negative feedback mechanisms. Cell Tissue Kinet 1982; 15: 611-22.

16 Clarke RM. Progress in measuring epthelial turnover in the villus of the small intestine. Digestion $1973 ; 8$ : 16175.

17 Ross GA, Mayhew TM. Effects of fasting on villi along the small intestine: a stereological approach to the problem of quantifying villus 'shape'. Experientia 1984; 40: $856-7$.

18 Elias E, Dowling RH. The mechanism for small bowel adaptation in lactating rats. Clin Sci Mol Med 1976; 51: 427-33.

19 Campbell RM, Fell BF. Gastrointestinal hypertrophy in the lactating rat and its relation to food intake. $J$ Physiol (Lond) 1964; 171: 90-7.

20 Goodlad RA, Wilson TJG, Lenton W, Gregory H, McCullough KG, Wright NA. Urogastrone-epidermal growth factor is trophic to the intestinal epithelium of parenterally fed rats. Experientia 1985; 41: 1161-3.

21 Levine GM, Deren JJ, Steiger E, Zinno R. Role of oral intake in maintenance of gut mass and disaccharide activity. Gastroenterology 1974; 67 : 975-82.

22 Clarke RM. Luminal nutrition versus functional workload as controllers of mucosal morphometry and epithelial replacement in the rat small intestine. Digestion 1976; 15: 411-29.

23 Wright NA, Alison M. The biology of epithelial cell populations. Vol 2. Oxford: Clarendon Press, 1984: 743-76, 842-68.

24 Jacobs LR, Bloom SR, Dowling RH. Response of plasma and tissue levels of enteroglucagon immunoreactivity to intestinal resection, lactation and hyperphagia. Life Sci 1981; 29: 2003-7. 